University of Michigan Law School

University of Michigan Law School Scholarship Repository

Articles

Faculty Scholarship

2005

\title{
Detroit Area Study on Financial Services: What? Why? How?
}

Michael S. Barr

University of Michigan Law School, msbarr@umich.edu

Available at: https://repository.law.umich.edu/articles/59

Follow this and additional works at: https://repository.law.umich.edu/articles

Part of the Banking and Finance Law Commons, Law and Society Commons, and the Social Welfare Law Commons

\section{Recommended Citation}

Barr, Michael S. "Detroit Area Study on Financial Services: What? Why? How?" Law Quad. Notes 48, no. 1 (2005): 72-7.

This Article is brought to you for free and open access by the Faculty Scholarship at University of Michigan Law School Scholarship Repository. It has been accepted for inclusion in Articles by an authorized administrator of University of Michigan Law School Scholarship Repository. For more information, please contact mlaw.repository@umich.edu. 


\section{Detroit Area Study on Financial Services: What, Why \& How}

The following article is based on a talk give by Assistant Professor of Law Michael S. Barr to the University of Texas Law School-Harvard Law School Joint Conference on Commercial Law Realities in Austin, Texas, in April. Barr was selected by the University of Michigan's Institute for Social Research, Survey Research Center to be the faculty investigator for the Detroit Area Study, which the University has conducted for more than 50 years. Barr is using the study to explore the financial services needs of low- and moderate-income households, building on his groundbreaking analysis in Banking the Poor. Barr raised a total of more than $\$ 800,000$ from the Ford Foundation, the MacArthur Foundation, the Fannie Mae Foundation, the Casey Foundation, and the Mott Foundation, as well as University sources, for the study. Barr is beginning field work this summer.

\section{By Michael S. Barr}

For most of us, getting our paychecks directly deposited into our bank accounts, writing a check, or storing our money in an account can be taken for granted. We often struggle to save for longer-term goals, our children's education, or retirement, but most of us, most of the time, do not worry whether our savings or insurance will be enough to get us through an illness, or even loss of a job.

For most low- and moderate-income households, the picture is quite different. High cost financial services, barriers to saving, the lack of insurance, and credit constraints may contribute to poverty and other socio-economic problems. Low-income individuals often lack access to financial services from banks and thrifts, and turn to alternative financial service providers such as check cashers, payday lenders, and money transmitters. ${ }^{\mathrm{i}}$ Low-income households may also face high costs for these kinds of services, and some may find it more difficult to save and plan financially for the future. Living paycheck to paycheck may leave them vulnerable to emergencies that may endanger their financial stability, given the lack of insurance for key life events, and the lack of longer-term savings may undermine their ability to invest in human capital, purchase a home, and build assets. High cost financial services may reduce the value of government income transfer programs such as the Earned Income Tax Credit. 
Despite these differences, all of us rely on financial services in our daily lives. Yet economists often have a difficult time figuring out we why all behave the way we do. Many of us save less than we should, borrow more than we ought, and get ourselves entangled in financial transactions that make little sense to an outside observer. Recent research in behavioral economics has challenged many of the central assumptions of economic theory regarding household financial decision making.

I have begun an empirical project to study these issues with an in-depth household survey in the Detroit metropolitan area. This essay introduces the study, explores competing theoretical frameworks that motivate the inquiry, describes the survey methodology, and provides an update on the status of the project.

\section{The Detroit Area Study}

I was selected by the University of Michigan's Institute for Social Research, Survey Research Center (SRC) to be the faculty investigator for the Detroit Area Study (DAS) for 2005. The DAS has been conducted under the auspices of SRC for more than 50 years. I will survey low-, moderate-, and middle-income households from the Detroit metropolitan area about (1) how and why they use a wide array of financial services, as well as the costs and benefits of such services; and (2) how they would respond to new types of cost-effective financial products tailored to their needs. In addition, I have geocoded all financial services firms in the three-county area, including more than 1300 check cashers, pawn shops, payday lenders and tax preparation firms, and more than 350 banks, thrifts, and credit unions. I will be using mail and telephone surveys to gather information about the prices and products offered by this wide range of firms.

Broadly speaking, my research aim is to develop a comprehensive understanding of the financial services behaviors of low- and moderate-income households and the financial services constraints that they face. My goal is both to inform the theoretical debates on key questions regarding household financial decision-making and to contribute to the development of policies to expand access to financial services.

\section{Theoretical inquiry}

The study can help to inform theoretical debates among traditional economic models, behavioral economics, and social network theories regarding low- and moderateincome households. In this short space, I briefly set out competing theories, and explore 
implications of these theories in five key areas: saving, credit, transactional services, insurance, and household preference formation. I suggest for each area the kind of questions that the study may contribute to answering.

Basic assumptions about how people behave shape our understanding of economics and our views about the role of law. Traditional economic models of rational choice view decisions as made by optimizing rational agents with perfect foresight. Research in psychology and behavioral economics provides alternative explanations for decision-making, such as the importance of default rules, framing, and heuristics. ${ }^{\mathrm{ii}}$ Behavioral economists focus on the limits of our rationality. By contrast, the public debate is largely consumed by "culture of poverty" theories of social deviance, laziness, imprudence, and impatience as descriptions for the behavior of the poor.

These differing frameworks affect how one views a wide range of phenomena, such as savings behavior, risk-taking in investment, and insurance. The behavioral economic insight, for example, regarding default rules, can be used not only to understand individual choice, but also, perhaps, to design institutions to influence individual decision-making. ${ }^{\text {iii }}$ That is, our understanding of how individuals make decisions can have profound implications for differing approaches to the role of law in such areas as consumer protection, disclosure, bankruptcy, and national savings policy. Little empirical work has attempted to translate these theories into the world inhabited by low-income households in the United States. Bertrand argue that "the poor may exhibit the same basic weaknesses and biases as do people from other walks of life, except that in poverty, with its narrow margins for error, the same behaviors often manifest themselves in more pronounced ways and can lead to worse outcomes., ${ }^{\text {iv }}$ By contrast, Duflo suggests that the stress of poverty "almost certainly affects the way people think and decide" and that "[w]hat is needed is a theory of how poverty influences decisionmaking, not only by affecting the constraints, but by changing the decision-making process itself." provide information on household financial behavior and attitudes, and the constraints that such households face.

One important area for analysis of these differing frames involves savings. The dominant rational choice model is the "life cycle" theory, which suggests that savings are 
used to smooth consumption over one's life. ${ }^{\text {vi }}$ An extension of the rational choice model posits that precautionary motives also influence saving; that is, rational individuals with full foresight save as a form of insurance in the face of uncertainty. ${ }^{\text {vii }}$ Behavioral models suggest that, although these rational choice theories may be useful at the aggregate level, individual choices regarding saving are profoundly affected by psychology: mental accounting, starting points, endowment effects and other frames. For example, groundbreaking empirical research by Richard Thaler at the University of Chicago has demonstrated the importance of framing, starting points, and default rules in determining whether and how much individuals will save in employer-sponsored retirement plans. ${ }^{\text {vii }}$

Little empirical research is directed at savings among low- and moderate-income households in the United States. How and why do low-income households save? Which households are able to save? A “culture of poverty” theory would suggest that lowincome households that do not save have different preferences, or values (thrift, prudence, work ethic) from other households. A behavioral theory would suggest that access to different forms of financial institutions or the opportunity for direct deposit at work might affect saving by affecting individual choices through institutional channels. That is, having a bank account, or using direct deposit at work, may contribute to saving apart from rational choice models of saving. A demonstration project involving “Individual Development Accounts” for low- and moderate-income households suggests that institutional structure affects savings. ${ }^{\text {ix }}$ The life cycle theory predicts higher savingsto-income ratios than data suggest that the poor exhibit, but failures in measuring how low-income people save may be at fault. Moreover, under plausible assumptions regarding the hard budget constraints of poverty, a rational choice theory would explain that low-income households do not save because they are poor; there are simply insufficient funds to set aside each month after necessities. Put another way, no current savings could be the rational choice in smoothing consumption over one's life. Other rational choice models predict lower savings because social safety net programs reduce the need to save as a precautionary measure against income shocks. ${ }^{\mathrm{x}}$

Yet the rational choice model is confronted with a puzzle: Lots of households that should save don't, and evidence from other studies suggests that some low-income households do save. Why do these households save and how are the able to do so? Do 
families save out of a precautionary motive, to build human capital through education, to save for retirement, or for other goals? What is the effect of saving on the ability of households to weather hardships, such as job loss or injury? How are households able to save? What is the role of "mental accounting," in which different sources of income are used for different functions? Are tax refunds, including from the Earned Income Tax Credit, an important form of saving, and do households view tax refunds as a time to commit to future saving? Answers to these questions can inform debates over pension law reform and Social Security, as well as private sector initiatives to encourage savings.

A second important area involves credit. Liquidity constraints can affect consumption, savings, work incentives, insurance, and time horizons for financial decision-making. Yet little empirical work has been done until recently on the credit constraints facing low-income households. ${ }^{\text {xi }}$ What kind of liquidity constraints do lowand moderate-income households face? What are the causes and consequences of such constraints? To what extent do the choices among different credit channels used by households, for example, banks, payday lenders, pawnshops and refund anticipation lenders, reflect credit constraints, different preferences (for example, convenience), or other factors? Why do such households borrow? For example, do households take out refund anticipation loans because they are impatient, need to pay off their bills, or have to pay the tax preparer? What are consumer attitudes towards credit, the consequences of delinquency, and bankruptcy and to what extent are differing attitudes, if any, reflected in behavior? To what extent do consumers understand credit terms, such as minimum payment terms on credit cards? Answers to these questions could lead to better disclosures and could inform the debate over bankruptcy reform.

A third important area involves transactional services. One theory suggests that use of check cashers is simply a rational response to those with preferences for convenience and impatience. A behavioral economics approach focuses on the role of social networks in a neighborhood in conditioning individual choice. Economic network theory suggests instead a focus on conflicting payments systems: Employers pay by check while landlords and other businesses in low-income communities accept cash. An institutional focus combines these insights to suggest looking at the structure of banking to explore these transaction costs. 
Welfare economics largely treats income as if it were cash (or a fully liquid intangible) for purposes of determining utility. What happens to the model if the transaction costs of converting income into useable form are high relative to income? As a normative matter, as I argued in Banking the Poor, the costs of converting income into cash may be grounds for a non-income form of redistribution of financial services. But these theories require knowing the size and direction of some key parameters. For example, does proximity to different types of financial services affect financial services usage patterns, preferences, and needs? Do price and product offerings explain such matters? Are other factors, such as hassle, habit, or employment patterns what is really at work? Does access to a bank account affect saving and credit?

Fourth, low- and moderate-income households face risks to their health, income, employment, household structure, and the like. To what extent are such households insured against such risks? Measures of insurance include formal insurance mechanisms, such as unemployment, disability, and health insurance, as well as informal mechanisms and credit, such as borrowing from friends and family, or self-insuring through savings, holding durables, or other means. Empirical research can contribute to our understanding of the extent to which low-income households are under-insured, and can begin to tease out the links among insurance, savings, and credit as substitutes in providing a cushion against hardship for low- and moderate-income households. To what extent can financial hardships be understood as insurance failures?

Fifth, empirical research can contribute to a better understanding of household preference parameters, ${ }^{\text {xii }}$ such as risk tolerance and future-orientedness, and their influence on decision-making with regard to savings, insurance, credit and the like. To what extent does heterogeneity of preferences explain behavior? Alternatively, to what extent are household preferences and behaviors shaped by how available choices are framed for them? How predictive are economic measures of risk tolerance? What is the relationship between risk tolerance and income? Are low-income households more risk tolerant because they have little to lose, or more risk averse because they have no cushion to fall back on? Does risk aversion contribute to lower levels of borrowing and lower returns to capital? Are low-income households more impatient than others as measured by time preference and inter-temporal rates of substitution? ${ }^{\text {xiii }}$ Do households save more 
because of an underlying propensity to plan or because of the savings choices they are offered? Is the lack of self-control an important factor explaining saving and borrowing decisions or are such matters driven by hard budget constraints? Understanding heterogeneity in preferences can lead to better modeling of economic behavior under both rational choice and behavioral models.

Lastly, in additional to these theoretical contributions, empirical research can contribute to policy debates and private-sector decision making regarding product offerings. For example, this research will provide guidance to federal government policy makers about the savings needs of low- and moderate-income households as Congress and the executive branch are considering Social Security and tax changes that will affect savings policy across the income spectrum. Low- and moderate-income households likely present quite different challenges - and opportunities — to policy makers than other households. The research will also contribute to other efforts, both private sector and governmental, to expand access to financial services. For example, one product from the research will be a market model enabling financial institutions to measure possible takeup rates among low- and moderate-income urban households for different forms of costeffective financial products. Thus, the research is also designed to assist efforts to increase the financial services opportunities of low- and moderate-income households.

\section{Methodology}

The project contains four main components:

- The household survey measures financial services usage patterns, attitudes and preferences, demographics, income, wealth, and employment characteristics.

- The conjoint portion of the study uses choice based methodology to measure household financial services preferences.

- The non-bank financial institutions survey captures information about the price and product offerings of check cashers, grocery and other stores that cash checks, as well as payday lenders, pawnbrokers, and tax preparation firms.

- The bank telephone survey captures price and product information on bank accounts offered by area depository institutions.

Together, these four instruments will provide a comprehensive picture of low- and moderate-income financial services demand and supply in the Detroit area. 


\section{Household survey}

We will conduct computer-assisted, personal interviews with households in the Detroit metropolitan area, which includes Wayne, Oakland, and Macomb counties. Each interview, to be conducted by SRC field staff, will last approximately 60 minutes. Inperson interviews enable interviewers to reach low- and moderate-income households more systematically than telephone interviews, and permit interviewers to ask sensitive questions about financial services that households may be reluctant to answer by phone.The target sample for the DAS is a stratified random sample of 1,000 completed household interviews. I have divided census tracts into three strata: Low-income (at or below $60 \%$ of area median); Moderate-income (61-80\% of area median); and Middleincome (81-120\% of area median). The 1,000 interviews will include 600 in the low income stratum, 300 in the moderate income stratum, and 100 in the middle income stratum. For all three strata combined, we expect to need a total starting sample of 1,859 listed households in order to obtain 1,000 completed interviews. SRC field staff have listed the sample from 150 segments of the Detroit metropolitan area. The sampling frame for the first-stage selection is a frame of all census blocks in the area. The sampling frame for the second-stage selection of households is a listing of all housing units in the selected segments. Households will be randomly selected from these segments, and a randomly selected adult in the household will participate in the survey. The data collected will generalize to a random sample of households and individuals.

\section{Conjoint analysis}

I developed the conjoint methodology with Ed Bachelder of Dove Associates using CBC software from Sawtooth Technologies. The conjoint analyzes respondent preferences for different types of payment-card technologies that can be used for income receipt. It is difficult to measure preferences from observed behavior, because behavior derives from the intersection of preferences and constraints. Using hypothetical products permits direct measurement of preferences.

The conjoint methodology uses a repeated measures technique. Each respondent will be shown a series of 12 cards. Each card contains columns with three product options - a debit card, a payroll card, and prepaid debit card - and a choice of "none of the above.” The product offerings are realistic composite products based on my research 
regarding existing product offerings and discussions with financial institutions and vendors about plausible variations. Nine rows contain product attributes, tested at different levels, for each product, such as fees, deposit features, bill payment, savings features, credit background checks, and consumer protection. Product features are constructed with an orthogonal design that will permit assessment of the importance of different features to the respondent's choice of product. Using multinomial logistical regression models, one can estimate the importance of each product feature (e.g., price, savings plan) in the consumer's choice of products, as well as "take rates" for hypothetical products, although such data will be analyzed as measuring consumer preference, rather than actual behavior. Three versions of the conjoint, with a common “holdout” card, will be randomly administered to control for the possibility of design order bias. By combining conjoint analysis with demographic, behavioral and preference information from the household survey, we will be able to control for factors, such as race, age, and gender, that may be correlated with preferences.

\section{Non-bank financial institution mail survey}

I developed a list of 1,365 non-bank financial institutions in the three-county area relying on a variety of sources. Institutions that cash a certain number of checks are subject to federal reporting requirements as money service businesses, including money transmitters, grocery stores, check cashers, payday lenders, and liquor or convenience stores. This dataset was supplemented by web-based telephone listings for these types of firms, as well as with listings for tax preparation firms and pawnbrokers. I developed a pen and paper mail survey, which is being sent out to such institutions on their key prices and products of interest. We will use geographic proximity analysis, and price and product analysis to examine constraints facing low- and moderate-income households derived from the location of financial institutions and the cost and availability of useful products, as well as how such constraints affect preferences and behavior.

\section{Bank telephone survey}

All 380 branches and headquarters of all banks, thrifts, and credit unions in the three-county area have been geocoded and listed using datasets from the FDIC, the National Credit Union Administration, and Michigan regulatory agencies. Depositories in 
the Detroit area will be contacted by telephone to determine price offerings on key banking products of interest. These data will also be checked against web listed prices.

\section{Project status}

I have formed an advisory board that includes James Carr (Fannie Mae Foundation), John Caskey (Swarthmore), Phoebe Ellsworth (University of Michigan Law

School), Reynolds Farley (Institute for Social Research), Jeane Hogarth (Federal Reserve Board), Rochelle Lento (University of Michigan Law School), Sherrie Rhine (Federal Reserve Board), Bob Shoeni (Institute for Social Research), and Michael Stegman (University of North Carolina, Chapel Hill). I am also consulting widely with other experts in the field.

To carry out the survey, I raised a total of more than $\$ 800,000$ from the Ford Foundation, the MacArthur Foundation, the Fannie Mae Foundation, the Casey Foundation, the Mott Foundation, the Provost's Office, the Office of the Vice President for Research, the Center on Local, State and Urban Policy, and the National Poverty Center.

During fall 2004 and winter 2005, I developed the sampling plan, as well as the household survey and the conjoint analysis that will be administered to households, and, separately, a mail survey that will be sent to area financial service providers to determine key supply data. The survey instruments have gone through numerous drafts, and have been vetted by my advisory board, outside academic experts and practitioners, and an ISR survey methodology team expert in cognitive and interpretive problems. The instruments have been pretested by law school students and SRC field staff. We undertook cognitive interviews, in which core questions are discussed with households demographically similar to the sample to get a better understanding for respondent comprehension and decision making. We also conducted a pretest on a representative sample of low- and moderate-income households. After pre-testing and survey modifications, we will be in the field for interviewing during the summer.

\section{Conclusion}

Studying the financial decision making of low- and moderate-income households can help to illuminate a world that is often hidden in plain sight. How many of us walk by the signs for "Checks Cashed Here," "Money Orders for Sale,” and "Payday Loans: Get Cash Quick” without thinking about the implications of those signs for the daily lives of lower-income households? By exploring these issues in the Detroit Area Study, I hope to 
reveal this reality, and to shed light on fundamental questions regarding how people behave that are at the core of current legal debates based on advances in behavioral psychology and economics.

Assistant Professor of Law Michael S. Barr, who joined the faculty in fall 2001, teaches Financial Institutions, Jurisdiction and Choice of Law, and Transnational Law. He served as chair and now is on the executive committee of the Section on Financial Institutions of the Association of American Law Schools. Barr earned his B.A., summa cum laude, with Honors in History, from Yale University, an M. Phil. in International Relations from Magdalen College, Oxford, as a Rhodes Scholar, and his J.D. from Yale Law School. Barr served as a judicial clerk for Justice David H. Souter of the Supreme Court of the United States, and for Judge Pierre N. Leval, then of the Southern District of New York. His wide experience includes serving as: special adviser and counselor on the Policy Planning Staff of the U.S. State Department; Treasury Secretary Robert E. Rubin's special assistant; deputy assistant secretary of the Treasury; and special adviser to the President. Barr is a nonresident senior fellow at the Brookings Institution and a member of the bars of New York and the District of Columbia.

\footnotetext{
iSee generally, Michael S. Barr, Banking the Poor, 21 Yale Journal On Regulation 121 (2004).

ii See, e.g., Daniel Kahneman and Amos Tversky, ChOICES, VALUES, AND FrAMES (2000).

iii See, e.g., Cass R. Sunstein \& Richard Thaler, Libertarian Paternalism is Not an Oxymoron, 70 U. ChicAgo L. ReV. 1159 (2003); Richard Thaler \& Cass Sunstein, Libertarian Paternalism, 93 AM. ECON. REV. 175 (2003); Colin Camerer, et al., Regulation for Conservatives: Behavioral Economics and the Case for “Asymmetric Paternalism,” 151 U. PA. L. REV. 1211 (2003); Michael Sherraden and Michael S. Barr, Institutions and Inclusion in Savings Policy, in Nicolas Retsinas and Eric Belsky, eds., BuILDING AsSETS, Building Credit: CREating WeAlth in LOW-InCome Communities (2005).

iv Marianne Bertrand, Sendhil Mullainathan, and Eldar Shafir, A Behavioral-Economics View of Poverty, 94 AM. ECON. REV. 419 (2004).

${ }^{v}$ Esther Duflo, Poor but rational?, in A. Banerjee et al., eds., What Have We LeARnt About PoverTy? (2004).

${ }^{\mathrm{vi}}$ F. Modigliani and R. Brumberg, Utility Analysis and Aggregate Consumption Functions: An Interpretation of Cross-Section Data, in K. Kurihara, ed., POST-KEYNESIAN ECONOMICS (1954) (life cycle); Milton Friedman, A theory of consumption function, NBER (1957) (permanent income).

vii Christopher D. Carroll, The Buffer-Stock Theory of Saving: Some Macroeconomic Evidence, BROOKINGS PAPERS ON ECONOMIC ACTIVITY, No. 2 (1992).

viii See Richard H. Thaler and Shlomo Benartzi, Save More Tomorrow: Using Behavioral Economics to Increase Employee Saving, 112 J. PoliT. ECON. (2004); James J. Choi, et al., Defined Contribution Pensions : Plan Rules, Participant Choices, and the Path of Least Resistance, in James M. Poterba, ed., 16 TAX Policy And the ECOnOMy 67 (2002); Brigitte C. Madrian and Dennis F. Shea, The Power of Suggestion: Inertia in 401(k) Participation and Savings Behavior, 116 Q. J. EcON. 1149 (2001).
} 
${ }^{\text {ix }}$ See Sherraden and Barr, supra.

${ }^{x}$ James P. Ziliak, Income Transfers and Assets of the Poor, 85 REV. OF ECONOMICs \& STATISTICs 63 (2003).

${ }^{\mathrm{xi}}$ See Barr, Banking the Poor, supra; Michael S. Barr, Credit Where it Counts: The Community Reinvestment Act and Its Critics, 80 NEW York UNIVERSITY LAW REVIEW (2005).

xii See, e.g., Robert B. Barsky, F. Thomas Juster, Miles S. Kimball, and Matthew Shapiro, Preference

Parameters and Behavioral Heterogeneity: An Experimental Approach in the Health and Retirement Study, Q. J. OF ECON. 537 (May 1997).

xiii See, e.g., Emily Lawrence, Poverty and the Rate of Time Preference: Evidence from Panel Data, $99 \mathrm{~J}$. OF POLIT. ECON. 54 (1991). 